\title{
APRESENTAÇÃO
}

Já há algum tempo, vem sendo desenvolvido um número crescente de pesquisas no campo educacional na perspectiva dos estudos foucaultianos, que se caracterizam, na maioria das vezes, por abordarem de modo inovador temas de relevância no cenário contemporâneo. Essas investigações enfatizaram, em um primeiro momento, o conceito de "poder disciplinar", desenvolvido pelo filósofo naquela que é, possivelmente, sua obra mais conhecida: o livro Vigiar e punir, publicado em 1975.

Porém, mais recentemente, observamos o surgimento de diversas pesquisas que ainda transitam pelas teorizações foucaultianas acerca do poder, mas que deslocam sua ênfase para os conceitos de biopoder e governamentalidade, que surgem na obra do autor na segunda metade da década de 70. De acordo com o próprio Foucault, o biopoder surge cerca de um século após o poder disciplinar, não para promover seu desaparecimento, nem mesmo enfraquecimento. Essas duas formas de exercício de poder se articulam e se reforçam mutuamente, potencializando seus efeitos. Essa outra modalidade de exercício de poder, diferentemente da disciplina, não tem por alvo o corpo dos indivíduos, mas a população. Ou seja, enquanto a disciplina atua preferencialmente no nível de uma microfísica, a biopolítica produz seus efeitos no domínio mais amplo da população. Se o propósito do poder disciplinar era a docilização do corpo, o propósito do biopoder é a maximização da vida da população.

O uso dos conceitos de disciplina e biopoder já tornara possível uma produção acadêmica ampla e instigante. Porém, a publicação, nos últimos anos, das transcrições dos cursos de 1977-1978 - Segurança, território, população e de 1978-1979 - Nascimento da biopolítica -, ministrados por Foucault no Collège de France, deu acesso a um conjunto de teorizações que se desdobram em possibilidades de pesquisa particularmente interessantes. Nesses cursos, Foucault apresenta a noção de governamentalidade, analisando a emergência 
do liberalismo e sua transformação em neoliberalismo; surgem novas e potentes ferramentas de trabalho. É importante notar que o pensamento foucaultiano não restringe o liberalismo e o neoliberalismo a doutrinas políticas, mas mostra que se constituem em algo muito mais amplo: são racionalidades que orientam os modos de conduzir os comportamentos de indivíduos e de populações, incidindo diretamente nos modos de produção de subjetividades. E é essa base conceitual que une os artigos desta seção temática, constituída por dois artigos de pesquisadores brasileiros e um artigo produzido por pesquisadores colombianos, todos inéditos. Nosso objetivo é divulgar esses trabalhos, que analisam questões relativas ao campo educacional a partir de uma perspectiva original, no intuito de produzir outros olhares sobre as temáticas abordadas.

O primeiro artigo, "Educar es gobernar: la educación como arte de gobierno”, de Carlos Noguera-Ramírez e Dora Marín-Días, mostra como a educação funcionou, desde a Modernidade, como elemento central da governamentalidade, sendo que suas estratégias sofrem modificações ao longo do tempo. Eles identificam três períodos com diferentes ênfases: ensino e governamentalidade disciplinar, nos séculos XVI a XVII, educação e governamentalidade liberal, nos séculos XVIII e XIX, e educação e governamentalidade neoliberal, característica dos dias de hoje.

O segundo artigo sai do ambiente escolar, sem abandonar a educação. "Programas trainees corporativos e o governo das almas", de Jairo da Cruz e Karla Saraiva, apresenta uma sucinta análise das transformações do mundo do trabalho na passagem da Modernidade para a Contemporaneidade e analisam três programas trainees, destinados a capturar "grandes talentos" egressos de cursos superiores. A análise está baseada em um quadro teórico que mostra a passagem de uma ênfase moderna em trabalhadores com corpos dóceis, capazes de obedecer a regulamentos e submetidos à vigilância, para uma ênfase contemporânea, que visa a agenciar sujeitos governáveis, capazes de agir como empresários de si.

No artigo seguinte, "Governamentalidade democrática e ensino de Filosofia no Brasil contemporâneo”, Silvio Gallo analisa alguns documentos que orientam a introdução dessa disciplina no ensino médio brasileiro como um instrumento para a formação de jovens segundo aquilo que se entende como uma sociedade democrática moderna, instalando nesse movimento uma teorização acerca do que seria uma governamentalidade democrática que estaria sendo gestada no Brasil desde a década de 80 do século 20.

\section{ALFREDO VEIGA-NETO}

alfredoveiganeto@uol.com.br

KARLA SARAIVA

karlasaraiva@via-rs.net 